Journal of Educational

Technology \& Online Learning

Volume 4 | Issue $3 \mid 2021$

http://dergipark.org.tr/jetol

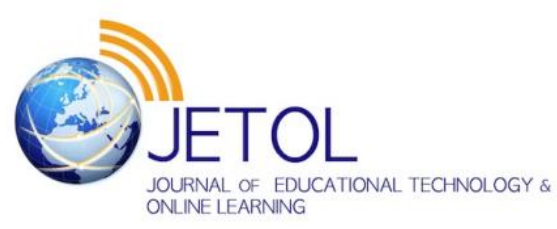

\title{
Bibliographic review. Existence of virtual museums for educational purposes is applied to the professional environment.
}

\author{
Roberta Barban Franceschi ${ }^{a}$ (D), Laura de Miguel Álvarez ${ }^{a}$ (D) \\ ${ }^{a}$ Universidad Internacional de La Rioja (UNIR), Spain.
}

Suggested citation: Franceschi, R. B. \& de Miguel Álvarez, L. (2021). Bibliographic review. Existence of virtual museums for educational purposes is applied to the professional environment. Journal of Educational Technology \& Online Learning, 4(3), 464-474.

\begin{tabular}{l} 
Article Info \\
\hline Keywords: \\
Virtual museums, \\
Bibliographic Review, \\
Professional, educational \\
innovation, digital learning.
\end{tabular}

Review Article

\begin{abstract}
Virtual museums are the answer a digital society, a new cultural, social, and economic system and a tool for educational innovation and digital learning. This article aims to collate all relevant evidence in virtual cultural museums with a teaching approach and detect what is published using the following question "What is published about virtual museums for educational purposes?". Its objective is to verify what can be found in the academic field about virtual museums for didactic purposes applied to the professional environment. The research analyzes two hundred and twenty-three articles, of which seventeen were selected for their didactic and professional environment characteristics. The bibliographic review presents indicators that determine a virtual museum is an effective tool both in the field of reinforcing learning, as well as in the theoretical and practical development of activities that encourage creation by students.
\end{abstract}

\section{Introduction}

This article arises from verifying what publications are being made in virtual museums, specifically in digital learning linked to professional skills and competencies. The method selected to verify this context is the Preferred Reporting Items for Systematic Reviews and Meta-Analyses (PRISMA).

The objective of the bibliographic review is to collate all relevant evidence in the field of cultural virtual museums with a teaching approach and detect what is published in this regard using the following question "What is published about the virtual museum for educational purposes?". From there it is pursued:

- Identify what can be found in the academic field on the theme of virtual museums.

- Verifying which of the above are framed in the teaching field for didactic purposes applied to the professional environment.

The information generated in the systematic review is fundamental for the scientific interests of the research group Design, Society, Education and Art (DiSEA), on the theme "virtual museum", in which two research actions are located.

The first one is the "ESIT virtual museum", a didactic tool of the Design area of the Higher School of Engineering and Technology (ESIT) from the Universidad Internacional de La Rioja (UNIR - International University of La Rioja). This museum was created for educational purposes that encourages the STEAM methodology and interdisciplinary learning in business, scientific and social fields. We live in a society framed in the era of image and interactivity and this project encourages the dissemination of the best didactic results of the ESIT Design Area. At the same time, it is an innovation in the disseminating of the 
results obtained in classes and a recent initiative with a $100 \%$ online university like UINR (International University of La Rioja).

The second said museum will be one of the dissemination interfaces for the results obtained in the research carried out as an own project financed by UNIR entitled "The visibility of creative women in Spain in the XXI century". This project is being developed by the research group DiSEA - Design, Society, Education and Art - whose principal researcher is PhD Laura de Miguel, co-author of this article.

The bibliographic review carried out in this article is justified by these two mentioned reasons, both in digital teaching and learning and in the context of research.

UNIR is an online university that promotes research (in educational innovation and new technologies) with expert researchers in various methods and multidisciplinary research groups. Currently, UNIR has developed an advanced course to prepare articles on systematic review in research in Social Sciences, with the support of various experts in this method.

The article is divided into four parts. The first presents a brief literature review. The second part deals with the research method and its periods, arguing the bibliography search method and what have been the research parameters to answer the question "What is published about virtual museums for educational purposes?". The third presents the selection of articles and their analysis. It is verified that there are two profiles of virtual museums with didactic purposes, those that have physical headquarters but also have their virtual unit and are resources for reinforcing learning and virtual museums without physical headquarters. These museums are developed by students and teachers as a way of applying knowledge in practice and learning by doing.

The fourth part assumes the results obtained from the research that detects that virtual museums are an effective tool, both in reinforcing learning and in the theoretical and practical development of activities that encourage creation by the students themselves.

\section{Bibliographic Review}

In the framework of virtual museums thematic, an element to consider is the current society and the way communication is established. Technology has enabled the interaction between the physical and the virtual, favouring other types of relationships and has enabled greater access to information (Quiroga Sichacá, 2018), in short, a change in the way of communicating (Da Costa Santos \& Lima, 2014).

Virtual museums answer a digital society, a new cultural, social, and economic system, a technological and social environment of interaction, practices, and thoughts. Said technological environment with the cultural context is called Cyberculture (Lévy, 1997).

Cyberculture opens a reality of constant change and growth for museums. Besides globalization, openness, and multiculturalism, it enables continuous innovation in the use of technologies, content languages and adapting users' needs (Fernández de Castillo Santisteban, 2017).

According to the definition of the Consejo Nacional de Museos:

"A museum is a non-profit, permanent institution at the service of society and its development, open to the public, which acquires, preserves, investigates, communicates and exhibits the tangible and intangible heritage of humanity and its environment for purposes of education, study and recreation." Consejo Nacional de Museos (s.f)

A virtual museum broadens the service to society since borders are diluted since it can be accessed from anywhere on the planet and at any time since it is always open. In this sense, technology has made the ideology of André Malraux (1947) come true when he idealized a museum space without walls (Da Costa Santos \& Lima, 2014). 
According to Werner Scheweibenz (1998), virtual museums are constituted by a collection of digital objects made up of a variety of media, logically organized, in which the visitor communicates and interacts according to their interests and needs.

According to Ioannis Paliokas and Gerassimos Kekkeris (2008), virtual museums adopt different formats on the Internet:

- Digital art collections made up of digital images accompanied by the description of the work.

- Museums of virtual Reality (3D), virtual architectural spaces in which the visitor is an avatar, thus having the feeling of presence and interaction with the content between the avatar and the objects in three dimensions.

- Museums of social interaction, in which they develop collaborative capacities between the threedimensional world and with other visitors who interact with voice and text in real-time.

- Virtual museum Portals are entry points for virtual collections that are active on the Internet.

- Artist blogs, personal portfolios through blogs.

The closeness to society turns these spaces into a more powerful tool for teaching and for communicating the results to society, more universal, which produces a great impact on the cultural and artistic industry (Fernández de Castillo Santisteban, 2017).

\section{Method bibliographic review}

The systematic review is a method that works with relevant evidence, which meets previously established criteria, to answer a specific research question (Moher, et al, 2015). In this article the question is "What is published about virtual museums for educational purposes?" The PRISMA method (Moher et al, 2015) has been used as a guide to carry out the review. The method is divided into 17 steps structured into four sections: Administrative, Introduction, Methods and Data (Moher et al, 2015).

The search strategy was organized with the following parameters: SCOPUS search engine, the period from the 15th of October 2020 to the 3rd of November 2020, in articles published in journals and congresses from 2000 to 2020, in English, Spanish and Portuguese and in the field of Art, Technology and Humanities.

In the search bibliometric process, the descriptors 'online museum', 'web museum', 'physical museum', and 'virtual museum' have been selected. Given the diversity of definitions found in the articles on the theme of museums in virtual spaces, it was verified that virtual museum is the most used terminology, However, the results were not very significant. From the searches carried out with the words virtual museum, professional, learning, four were selected, which were the ones that generated significant information for the study.

Virtual museums present different terms such as "Cybermuseum", "online museum", "web museum", "digital museum", "net museum", words that are always in evolution (Da Costa Santos \& Lima, 2014; Schweibenz, 1998).

Both authors have collaborated to determine the protocols of the systematic review, being the author Franceschi the one who has been responsible for the combination of the keywords when selecting the articles related to the research area. It is desired to clarify that the systematic review carried out is not registered in PROSPERO (International Prospective Register of Systematic Reviews) since it is not from the health area.

In the first search on November 3, 2020, two articles were selected out of ten. The search engine SCOPUS was chosen with the equation (TITLE-ABS-KEY ("virtual museum") AND TITLE-ABS-KEY ("professional") AND TITLE-ABS-KEY (“learning")): 
- Katz, J.E., Halpern, D. Can Virtual Museums Motivate Students? Toward a Constructivist Learning Approach. J Sci Educ Technol 24, 776-788 (2015). https://doi.org/10.1007/s10956-015-9563-7

- Shaffer, D.W., Nash, P. \& Ruis, A.R. (2015) Technology and the new professionalization of teaching. $\quad$ Teachers College Record, $117 \quad$ (12), https://www.tcrecord.org/content.asp?contentid=18149

In the second selection on November 22, 2020. ten articles were selected out of one hundred seventy. The search engine SCOPUS was chosen with the equation (TITLE-ABS-KEY ("virtual museum") AND TITLE-ABS-KEY ("learning") AND NOT TITLE_ABS_KEY ("formal")):

- Bolognesi, C. \& Aiello, D. (2020). Learning though Serious Game: A digital design museum for education. Proceedings of The International Archives of the Photogrammetry Remote Sens. Spatial Inf. Sci., XLIII-B5-2020, 83-90. https://doi.org/10.5194/isprs-archives-XLIII-B5-2020-832020, 2020.

- Daniela, L. (2020). Virtual museums as learning agents. Sustainability, 12(7), 2698. http://dx.doi.org/10.3390/su12072698

- Del Valle, M., Broiero, X.A., Gacia-Romano, L. (2020). Museos virtuales iberoamericanos en español como contextos de enseñanza y aprendizaje de las ciencias naturales. Revista Eureka 17(1), 1301 https://doi.org/10.25267/Rev_Eureka_ensen_divulg_cienc.2020.v17.i1.1301

- Eichler, M.L \& Del Pinto, J.C. (2011). Development of a virtual museum of science in southern Brazil. In M.B. Nunes, \& P. Isaías (Eds). IADIS International Conference e-Learning 2011, 1, 260264. ISBN: 978-972-8939-38-0

- Ismaee, D.A \& Al-Abdullatif, A.M. (2016). The Impact of an Interactive Virtual Museum on Students' Attitudes Toward Cultural Heritage Education in the Region of Al Hassa, Saudi Arabia. International Journal Emerging Technologies in Learning 11 (4), 32-39. eISSN: 1863-0383

- İşlek, D. \& Danju, I. (2019). The Effect of Museum Education Practices Carried out on Virtual Teaching Environments on Prospective Teachers' Views. Revista de Cercetare Si Interventie 67, 114-135. https://doi.org/10.33788/rcis.67.8

- Paliokas, I., Sylaiou, S. (2016) The use of serious games in museum visits and exhibitions: A systematic mapping study 2016. 8th International Conference on Games and Virtual Worlds for Serious Applications, (VS-Games)2016, 1-8. https://doi.org/10.1109/vs-games.2016.7590371

- Santagati C., Galizia M., Basso A., La Russa F.M. (2019). Reshaping the Identity of University Museums: The Museo della Rappresentazione in Catania as Digital Innovation Hub for the Engagement of New Generations and the Development of the Territory. In: Luigini A. (eds) Proceedings of the 1st International and Interdisciplinary Conference on Digital Environments for Education, Arts and Heritage. EARTH 2018. Advances in Intelligent Systems and Computing, vol 919. Springer, Cham. https://doi.org/10.1007/978-3-030-12240-9_75

- Sylaiou, S., Mania, K., Paliokas, I., Pujol-Tost, L., Killintzis, V., \& Liarokapis, F. (2017). Exploring the educational impact of diverse technologies in online virtual museums. International Journal of Arts and Technology, 10(1), 58-84. _https://doi.org/10.1504/ijart.2017.083907

- Zaina, L. A., Eline, F. D. A., Góis, G. J. D. C., \& Leles, A. D. (2016) Intensifying the development of web-based Virtual Museum for e-Learning Domain. Isaías, P. (ed). Proceedings of the IADIS International Conference e-Learning 2016, 1, 3-10. ISBN 978-989-8533-57-9

In the third selection on November 29, 2020. two articles were selected out of thirty-one. The search engine SCOPUS was chosen with the equation (TITLE-ABS-KEY ("virtual museum") AND TITLE-ABS-KEY (learning) AND NOT TITLE-ABS-KEY ("formal")) AND (EXCLUDE (SUBJAREA, "SOCI") OR EXCLUDE (SUBJAREA, "ENGI") OR EXCLUDE (SUBJAREA, "MATH”) OR EXCLUDE 
(SUBJAREA, “DECI”) OR EXCLUDE (SUBJAREA, “BUSI”) OR EXCLUDE (SUBJAREA, “BUSI”), "PSYC") OR EXCLUDE (SUBJAREA, "MEDI") OR EXCLUDE (SUBJAREA, "MATE")) AND (EXCLUDE (LANGUAGE, "French") OR EXCLUDE (LANGUAGE, "Italian")) AND (EXCLUDE (DOCTYPE, “cr”) OR EXCLUDE (DOCTYPE, “bk”)):

- Hill, V., Mystakidis, S. (2012). Maya Island virtual museum: A virtual learning environment, museum, and library exhibit. 18th International Conference on Virtual Systems and Multimedia, 2012, 565-568. https://doi.org/10.1109/vsmm.2012.6365978

- Paliokas, I., Sylaiou, S. (2016) The use of serious games in museum visits and exhibitions: A systematic mapping study 2016. 8th International Conference on Games and Virtual Worlds for Serious Applications, (VS-Games)2016, 1-8. _https://doi.org/10.1109/vs-games.2016.7590371

In the fourth selection on November 20, 2020. two articles were selected out of twelve. The search engine SCOPUS was chosen with the equation (TITLE-ABS-KEY ("virtual museum") AND TITLE-ABS-KEY ("art") AND NOT TITLE-ABS-KEY ("heritage museum ") AND NOT TITLE-ABS-KEY (" heritage center ") AND NOT TITLE-ABS-KEY (physical) AND NOT TITLE-ABS-KEY (real) AND NOT TITLEABS-KEY (" virtual reality ")) AND (LIMIT-TO (DOCTYPE, "ar")) AND (LIMIT-TO (SUBJAREA, "ARTS:

- Bertacchini, F., Bilotta, E., Gabriele, L., Pantano, P., \& Tavernise, A. (2013). Toward the use of Chua's circuit in education, art, and interdisciplinary research: Some implementation and opportunities. Leonardo, 46(5), 456-463. https://doi.org/10.1162/LEON_a_00641

- Kampouropoulou,M., Fokiali, P., Efstathiou, I. \& Stefos, E. (2103). The Virtual Museum in Educational Practice. Review of European Studies 5, 4. 120-129. http://dx.doi.org/10.5539/res.v5n4p120

\section{Articles selection and analysis.}

\subsection{Articles selection}

Before addressing how the selection of the articles has been carried out, it is important to contextualize the museum's typologies, for a better understanding since the three types appear in the selection made. Ron Ascott (1996), a British artist and theorist in cybernetics and telematics, has created a classification that is divided into three types of web museums.

- The websites of physical museums are the first type.

- Works with their digital origin are the second type. Works in pixels destined for fabrics on computers, that is, works created by software in which the exhibition space is virtual environments in two-dimensional spaces.

- Digital works, generated by image creation software and allowing interaction with the environment that converges in the same environment, offering a repository of creativity and collaboration, an operations platform, and a seedbed of ideas are the third type.

In the third type, the computer enables the viewer to manipulate and transform the message through the interfaces and can be participate in the work (Loureiro, 2003). In the review we will see the three typologies, but it is important to note that DiSEA projects work with the second and third types.

The four selected searches add up to a total of 223 articles. Seventeen of them were selected. The way of doing it has been the critical reading of the summaries of the two hundred and twenty-three articles, with a data extraction process respecting the following criteria:

- Research that uses the museum to reinforce the learning of the syllabus. 
- Research that talks about the impact of museums in the theoretical/practical didactic context of learning the themes of the academic guide, where the museum enters as an exercise in classroom teaching. The student creates the entire museum from the work to the virtual space. The museum is the exhibition space for her work and that of others and towards society, so this criterion is what the practice together with the professional context addresses.

\subsection{Articles analysis}

Research that relates virtual museums with a learning reinforcement tool has a constructivist learning approach in which the use of technologies in learning provides students with some autonomy. Most of the investigations addressed here are virtual museums that have a physical location.

The virtual museum has a unique characteristic and that is that the student can access the information whenever he wants. In this way, it's a continuous learning beyond the space and time of the classroom. (İşlek \& Danju, 2019; Katz \& Halpern, 2015; Paliokas \& Kekkeris, 2008; Shaffer \& Nash, 2015; Sylaiou et al., 2017;).

Virtual Museums are like digital texts, they are digital tools to serve as a starting point for discussion, debate, and reflection, since they reinforce the content learned in class (Shaffer \& Nash 2015).

Virtual museums are a tool of applied knowledge (Del Valle et al., 2020), providing three types: conceptual, procedural, and attitudinal.

The elements of virtual museums encourage interaction and communication since the digital and interactive 3D content of museums can strengthen the motivation of students/visitors, unleashing aesthetic sensitivities, developing creativity, and providing new approaches that involve visitors in unique interactive experiences personalized for them (Sylaiou et al., 2017). The 3D in virtual museums promote constructivist pedagogy and "learning by doing".

They stimulate creativity, influence the interaction and learning experience of users, encouraging participation in the learning process, increasing understanding of the content. Virtual museums with their physical spaces increase the intention of users to visit the physical museum in the future. (Katz \& Halpern, 2015).

It is verified that these museums use various technological resources such as games and simulations. They also emphasize using social networks for new possibilities of interaction (teachers, students, and museum educators), to express doubts or comments on the topics developed in class. Social networks increase collaboration within and outside the group and with specialized museum personnel (Del Valle et al., 2020).

The gamification of the experience in virtual museums presents a new way of working with cultural education. It may show some resistance in teaching since it is necessary for teachers to learn new technologies for this to take place. The teacher must assist in well-defined game mechanics since navigation through the 3D camera alone may not offer the expected learning results when immersed in a virtual museum (Sylaiou et al., 2017).

Virtual museums provide a permanent and active learning environment. The activities effectively create a cooperative learning environment, as they improved cognitive and sensory skills, favouring the development of research skills, critical thinking, and creativity. They also increase the ability to make observations through visual perceptions (İşlek \& Danju, 2019).

The research of Eichler \& Del Pinto (2011) relates the development of a virtual museum with 2D digital works in 3D space. With interface design tools they create virtual exhibitions in museums for educational purposes. It is a platform created for students and teachers of formal, non-formal and informal education and for the general audience. The main objective of their proposal is the virtual museum to be a tool to stimulate creativity, innovation, experimentation, discussion and interdisciplinary nature. Thus, they 
propose that technologies and digital works can build critical and reflective knowledge learning environments.

In her article Daniela (2020) comments that virtual museums are a learning tool in which entertainment encourages the figure of the active visitor, fosters the explorer profile, and enhances the narrative with the varied use of technological solutions. In the research, she analyzes thirty-six museum applications and concludes that there is a significant development path. She understands that technology is a learning enhancer and defends the virtual museum is a great potential as learning agent since it works on digital materiality, helping in the visualization and in expressing abstract concepts. She highlights that it is a tool of autonomy the student or the visitor should learn alone. She also exposes that learning in the museum is enhanced by mobile applications that make it possible to interact with artefacts, with the narrator or explore art objects in detail. It is then possible to activate digital learning and individual reflection. The study considers virtual museums as agents of learning and interconnection between the virtual and the physical world.

According to Ismaeel \& Al-Abdullatif (2017), in educational institutions virtual museums play an important role in educational experiences as an element to reinforce learning. They argue that it is a crosscutting tool for integration between more traditional. And it's possible other practices innovative that promote the use of technologies, digital and multimedia design, and the Internet. They also find that they promote improved communication, collaboration, digital literacy, and student creativity. They comment that it is a tool that encourages constructivist learning in which you can experiment, test, and reach your own conclusions.

The investigations that speak of the impact of museums in the theoretical/practical didactic context of learning and professional are not experiences like the previous ones where students learn the content in class and the museum reinforces learning. Still, the museum encourages creation and publication of the results, this is applying the theory practising high school or university experiences.

In practice carried out in laboratories by Bertacchini et al., (2013), high school students between sixteen and eighteen years old produced art forms such as 2D and 3D images, sound compositions and music, also 3D environments. Therefore, the mode of communication of the works carried out aligns with the virtual museum of type three mentioned before. The researchers with this activity found that it is an effective method of teaching complex concepts in realistic environment in which students engage and motivate powerfully.

The practice carried out by Kampouropoulou et al., (2013) with secondary school students is a hybrid process, a learning process in which the students had to generate the material such as photos, interviews, and process them to publish in the virtual museum. This research detected a change in attitude about the content studied and integrating technologies providing holistic learning (Kampouropoulou et al., 2013). In addition, the students had an active role, in which interaction, initiative and creativity, and participation were encouraged. During the educational process, some students worked with the role of themselves and others as co-creators.

In the outreach programme of the University of Washington, the practice carried out by Hill \& Mystakidis (2012) instructs students to create 3D content. They address both practical and theoretical knowledge about virtual environments and 3D instructional design. They created a virtual world of Second Life in which users had the option of playing a memory game to learn about the Mayan culture, mixing learning and fun. The article highlights the transversality of areas such as library services and faculties for the development of the project.

The article by Paliokas \& Kekkeris (2008) analyzes a developed tool that allows students to publish their work, creating and maintaining the exhibitions. One of the points they observed is that technologies can be a beginning for disseminating student work in virtual museums. This tool aims to reduce the time and effort generally needed by programmers to create and render 3D environments. The experiment was carried out 
with elementary and middle school students. Most of the students responded positively using the virtual museum, which is why it is verified that the language of virtual reality and video games is a stimulus in the learning process.

The practice carried out by Santagati et al., (2019) encourages the participatory process of students and the use of technological tools in University Museums towards the awareness of society. The students chose a sample of works from the courses of Building Engineering and Architecture. They made a digital exhibition, developing 3D textured mesh models (obtained through digital photogrammetry or acquisition of laser scanning) using re-topology algorithms for 3D sculpture and virtual reality. The research observes that it is important to promote the visualization of information as an element that can be a pedagogical and cognitive resource, in addition to highlighting the importance of social networks as a communication and loyalty tool.

\section{Results}

The bibliographic review presents indicators that determine that the virtual museum is an effective tool. It's effective both in the field of reinforcing digital learning and in the theoretical and practical development of activities that encourage creation by students.

Virtual museums have a constructivist pedagogical approach (Katz \& Halpern, 2015; Ismaeel \& AlAbdullatif, 2017) being a tool for autonomous, permanent, and active (Daniela, 2020; İşlek \& Danju, 2019; Paliokas \& Kekkeris, 2008; Shaffer \& Nash, 2015; Sylaiou et al., 2017).

The virtual museums (3D) encourage interaction and communication and strengthen motivation. They promote the development of visual and aesthetic perceptions, improving cognitive and sensory skills and the development of creativity. In this three-dimensional context, gamification and simulation in virtual museums, present an educational innovation. A new way of working in education (Ismaeel \& Al-Abdullatif, 2017; Santagati et al., 2019).

Virtual museums (3D) promote a cooperative learning environment. They're supporting the acquisition of research skills, critical thinking, observation, and the improvement of the compression of content and interactive digital learning experiences (Ismaeel \& Al-Abdullatif, 2017; Katz \& Halpern, 2015; Kampouropoulou et al., 2013; Sylaiou et al., 2017).

The virtual museum is an effective method for teaching complex concepts in realistic environment and allows to development of transversal projects. Students are involved and motivated with the development of the activity; they adopt an active role in the projects. They promote interaction, initiative, creativity, and participation. They work with the part of students and as co-creators during the educational process (Bertacchini et al., 2013; Eicher \& Del Pinto, 2011; Hill \& Mystakidis, 2012; Ismaeel \& Al-Abdullatif, 2017;).

The tendency to combine virtual museum platforms with social networks is detected as a tool that increases collaboration within and outside the group and with specialized personnel, favouring new interaction of possibilities with teachers, students, and educators of museums (Del Valle et al., 2020).

There are also combinations of virtual museums with mobile applications that, when exploring art objects, favour a technology that enhances learning through the different ways of interacting with artefacts, with the narrator. They represent elements that activate digital learning and individual reflection connecting the virtual and physical world (Daniela, 2020).

In the bibliographic review, the three types of web museums classification mentioned by Ron Ascott (1996) have been detected. Thus, it is verified that the third type is more powerful than the others in cognitive and sensory stimulation and impact the student positively by promoting interaction, communication and strengthening motivation to learn. 
It is also detected that for there to be more theoretical/practical actions, most from type three, it is necessary for teachers to learn new technologies to promote these initiatives (Sylaiou et al., 2017).

\section{Conclusion}

The bibliographic review on the virtual museum theme proposes a powerful didactic tool in the context of digital learning, with vast possibilities in teaching given its potential of transversality, the use of a variety of technologies and the continuous development of virtual reality technologies.

It is observed that digital learning in virtual reality environments fosters cooperative knowledge, research skills, critical thinking, observation, and improved content compression.

Virtual museums (3D) are a tool to strengthen motivation, enhance the development of visual and aesthetic perceptions. They improve cognitive and sensory skills, and the development of creativity. In this context, it is necessary to highlight elements such as gamification, games, and simulation in virtual museums.

The virtual museum is an effective method for teaching complex concepts a realistic environment allowing the development of transversal projects and the learning reinforcement and development of professional skills. It is an autonomous, permanent, and active learning tool.

It also highlights the trend of combining virtual museum platforms with social networks to increase collaboration and communication, which raises the need for technological updating and training of teachers.

\section{References}

Ascott, R. (1996). The museum of the third kind. Intercommunication $n$. 15. Retrieved November 14, 2020 from http://www.ntticc.or.jp/pub/ic_mag/ic015/ascott/ascott_e.html

Bertacchini, F., Bilotta, E., Gabriele, L., Pantano, P., \& Tavernise, A. (2013). Toward the use of Chua's circuit in education, art, and interdisciplinary research: Some implementation and opportunities. Leonardo, 46(5), 456-463. https://doi.org/10.1162/LEON_a_00641

Bolognesi, C. \& Aiello, D. (2020). Learning though Serious Game: A digital design museum for education. Proceedings of The International Archives of the Photogrammetry Remote Sens. Spatial Inf. Sci., XLIII-B5-2020, 83-90. https://doi.org/10.5194/isprs-archives-XLIII-B5-2020-832020, 2020.

Consejo Nacional de Museos (s.f) La creación de una nueva definición de Museo - la columna vertebral del ICOM. Retrieved November 17, 2020 from https://icom.museum/es/recursos/normas-ydirectrices/definicion-del-museo/

Daniela, L. (2020). Virtual museums as learning agents. Sustainability, 12(7), 2698. http://dx.doi.org/10.3390/su12072698

Del Valle, M., Broiero, X.A., Gacia-Romano, L. (2020). Museos virtuales iberoamericanos en español como contextos de enseñanza y aprendizaje de las ciencias naturales. Revista Eureka 17(1), 1301 https://doi.org/10.25267/Rev_Eureka_ensen_divulg_cienc.2020.v17.i1.1301

Fernández de Castillo Santisteban, M.d.M. (2017). Museos y cibercultura, websites en la red [Doctoral Dissertation, Universidad de Sevilla. http://hdl.handle.net/11441/61113

Eichler, M.L \& Del Pinto, J.C. (2011). Development of a virtual museum of science in southern Brazil. In M.B. Nunes, \& P. Isaías (Eds). IADIS International Conference e-Learning 2011, 1, 260-264. ISBN: 978-972-8939-38-0 
Hill, V., Mystakidis, S. (2012). Maya Island virtual museum: A virtual learning environment, museum, and library exhibit. 18th International Conference on Virtual Systems and Multimedia, 2012, 565-568. https://doi.org/10.1109/vsmm.2012.6365978

Ismaeel, D.A \& Al-Abdullatif, A.M. (2016). The Impact of an Interactive Virtual Museum on Students' Attitudes Toward Cultural Heritage Education in the Region of Al Hassa, Saudi Arabia. International Journal Emerging Tecnologies in Learning 11, 4. 32-39. eISSN: 1863-0383

İşlek, D. \& Danju, I. (2019). The Effect of Museum Education Practices Carried out on Virtual Teaching Environments on Prospective Teachers' Views. Revista de Cercetare Si Interventie 67, 114 135. https://doi.org/10.33788/rcis.67.8

Kampouropoulou,M., Fokiali, P., Efstathiou, I. \& Stefos, E. (2103). The Virtual Museum in Educational Practice. Review of European Studies 5, 4. 120-129. http://dx.doi.org/10.5539/res.v5n4p120

Katz, J.E., Halpern, D. Can Virtual Museums Motivate Students? Toward a Constructivist Learning Approach. J Sci Educ Technol 24, 776-788 (2015). https://doi.org/10.1007/s10956-015-9563-7

Lévy, P. (1997). Cibercultura: La cultura de la sociedad digital. Anthropos Editorial.

Loureiro, M. L. de N. (2003). Museus de arte no ciberespaço: uma abordagem conceitual. Universidade Federal do Rio de Janeiro.

Moher, D., Shamseer, L., Clarke, M. Ghersi, D., Liberati, A., Petticrew, M., Shekelle, P., Stewart, L. \& Prisma-P Group. (2015). Preferred reporting items for systematic review and meta-analysis protocols (PRISMA-P) 2015 statement. Syst Rev 4, 1 (2015). https://doi.org/10.1186/2046-4053-41

Paliokas, I., Sylaiou, S. (2016) The use of serious games in museum visits and exhibitions: A systematic mapping study 2016. 8th International Conference on Games and Virtual Worlds for Serious Applications, (VS-Games)2016, 1-8. https://doi.org/10.1109/vs-games.2016.7590371

Quiroga Sichacá, L. (2018). Lo humano en la sociedad y cultura de la era digital. Revista Universidad de La Salle. 1. 71-84. ISSN 0120-6877.

Santagati C., Galizia M., Basso A., La Russa F.M. (2019). Reshaping the Identity of University Museums: The Museo della Rappresentazione in Catania as Digital Innovation Hub for the Engagement of New Generations and the Development of the Territory. In: Luigini A. (eds) Proceedings of the 1st International and Interdisciplinary Conference on Digital Environments for Education, Arts and Heritage. EARTH 2018. Advances in Intelligent Systems and Computing, vol 919. Springer, Cham. https://doi.org/10.1007/978-3-030-12240-9_75

Da Costa Santos, P., Lima, F. (2014). Museus e suas tipologias: o webmuseu em destaque. Retrieved November 03, 2020 from http://www.ies.ufpb.br/ojs/index.php/ies/article/download/16244/11491.

Shaffer, D.W., Nash, P. \& Ruis, A.R. (2015) Technology and the new professionalization of teaching. Teachers College Record, 117 (12), 1-30. https://www.tcrecord.org/content. asp?contentid=18149

Schweibenz, W. (1998). The "virtual museum": new perspectives for museums to present objects and information using the Internet as a knowledge base and communication system. Retrieved November $14, \quad 2020 \quad$ from http://www.informationswissenschaft.org/wpcontent/uploads/isi/isi1998/14_isi-98-dv-schweibenz-saarbruecken.pdf.

Sylaiou, S., Mania, K., Paliokas, I., Pujol-Tost, L., Killintzis, V., \& Liarokapis, F. (2017). Exploring the educational impact of diverse technologies in online virtual museums. International Journal of Arts and Technology, 10(1), 58-84. https://doi.org/10.1504/ijart.2017.083907 
Zaina, L. A., Eline, F. D. A., Góis, G. J. D. C., \& Leles, A. D. (2016) Intensifying the development of webbased Virtual Museum for e-Learning Domain. Isaías, P. (ed). Proceedings of the IADIS International Conference e-Learning 2016, 1, 3-10. ISBN 978-989-8533-57-9 